\title{
Hubungan Kecerdasan Sosial dengan Kepuasan Kerja Sama Kelompok dalam Small Group Discussion Pada Mahasiswa Program Studi Pendidikan Dokter Fakultas Kedokteran Universitas Udayana \\ Ni Putu Santika Dewi dan Ni Made Swasti Wulanyani \\ Program Studi Psikologi, Fakultas Kedokteran, Universitas Udayana santiikadewii@gmail.com
}

\begin{abstract}
Abstrak
Salah satu metode pembelajaran yang dilakukan di Fakultas Kedokteran Unud adalah Small Group Discussion (SGD) yaitu metode belajar dalam bentuk diskusi yang diikuti oleh mahasiswa dengan jumlah anggota antara 10 sampai 13 orang. Adanya kepuasan dalam kerja sama kelompok menyebabkan proses SGD akan menjadi lebih efektif. Oleh karena itu kepuasan menjadi faktor yang penting. Dalam SGD akan ada interaksi antara anggota kelompok, dan kualitas interaksi tersebut dipengaruhi oleh kecerdasan sosial anggota kelompok. Penelitian ini bertujuan untuk mengetahui hubungan antara kecerdasan sosial dengan kepuasan kerja sama kelompok di dalam SGD dan seberapa besar kepuasan mahasiswa dalam melakukan SGD. Subjek dalam penelitian ini adalah 274 orang mahasiswa Program Studi Pendidikan Dokter Fakultas Kedokteran Universitas Udayana. Instrumen dalam penelitian ini adalah skala Kecerdasan Sosial dengan koefisien reliabilitas sebesar 0,871dan skala Kepuasan Kerjasama Kelompok dengan koefisien reliabilitas sebesar 0,938 . Hasil analisis korelasi product moment menunjukkan angka korelasi sebesar 0,215 dengan taraf signifikansi sebesar $0,000(\mathrm{p}<0,05)$ yang berarti bahwa ada hubungan yang signifikan antara kecerdasan sosial dengan kepuasan kerjasama kelompok dalam SGD pada mahasiswa Program Studi Pendidikan Dokter Fakultas Kedokteran Universitas Udayana. Semakin tinggi kecerdasan sosial maka semakin besar pula tingkat kepuasan kerjasama kelompok, demikian pula sebaliknya samakin rendah kecerdasan sosial maka semakin rendah tingkat kepuasan kerjasama kelompok.
\end{abstract}

Kata Kunci : kecerdasan sosial, kepuasan kerjasama kelompok, Small Group Discussion.

\begin{abstract}
One of the learning methods in Faculty of Medicine, Udayana University is Small Group Discussion (SGD), which comes in the form of discussions, with 10 until 13 students participating. Satisfaction of group members in cooperating with each other makes SGD run more effectively. Therefore, satisfaction becomes an important factor. SGD creates interactions among group members, while the quality of the interactions is influenced by social intelligence of the group members. This research aims at finding out the correlation between social intelligence and satisfaction of students in cooperating during SGD, as well as finding out how satisfied the students are in doing SGD. The subjects of this research are 274 students of Medical Science Program, Faculty of Medicine, Udayana University. The instruments of this research are Social Intelligence scale with reliability coefficient 0,871 and Satisfaction of Group Cooperating scale with reliability coefficient 0,938 . The results from the analysis of product moment correlation indicates correlation number of 0,215 with significance level of $0,000(p<0,05)$, which means there is a significant correlation between social intelligence and satisfaction of students in cooperating during SGD participated by the students of Medical Science Program, Faculty of Medicine, Udayana University. Higher social intelligence results in higher satisfaction level of students in cooperating, and vice versa.
\end{abstract}

Keywords: social intelligence, satisfaction of group members in cooperating, Small Group Discussion 


\section{LATAR BELAKANG}

Pada negara-negara yang telah maju, pendidikan merupakan pilar yang sangat penting bagi negara. Pendidikan dapat menentukan bagaimana negara tersebut berkembang dan bagaimana kemajuan negara tersebut. Indonesia merupakan negara yang sedang berkembang dan pendidikan menjadi sarana utama untuk menentukan pembangunan suatu bangsa. Indonesia sedang mengalami masa pembangunan nasional yang menuntut disediakan sumber daya manusia (SDM) yang memiliki pengetahuan, sikap, dan jiwa pembangun. Tugas menyiapkan tenaga-tenaga tersebut diserahkan kepada sekolah setelah sebelumnya mendapatkan pendidikan informal di dalam lingkungan keluarga. Salah satu cara agar mendapatkan bibit SDM yang unggul adalah melalui media pendidikan.

Menurut juru bicara Badan Program Pembangunan PBB (UNDP), Tomi Soetjipto saat diwawancara oleh BBC Indonesia tanggal 24 Juli 2014 mengatakan bahwa Indonesia menempati peringkat 108 dari 187 negara dalam indeks pembangunan manusia (HDI). HDI merupakan indeks untuk mengukur perkembangan jangka panjang di tiga sektor utama pembangunan manusia, yaitu harapan hidup, akses terhadap pengetahuan, dan standar kehidupan layak. Akses pengetahuan yang menjadi salah satu indikator pembangunan manusia sejak tiga tahun terakhir tidak bergerak. Menurut Tomi, pendidikan adalah kunci bagi Indonesia untuk keluar dari apa yang disebut banyak orang sebagai jebakan kelas menengah yaitu stagnannya situasi perekonomian suatu negara karena gagal berkompetisi dengan negara-negara lain (BBC, 2014). Pada berita sebelumnya terlihat bahwa mutu pendidikan di Indonesia masih tergolong rendah dibandingkan dengan negara-negara lain. Salah satu cara keluar dari jebakan kelas menengah yaitu melalui program wajib belajar yang telah dibuat oleh pemerintah. Pemerintah Indonesia telah membuat kebijakan mengenai program wajib belajar. Kebijakan tersebut diatur dalam undang-undang nomor 20 tahun 2003 tentang sistem pendidikan nasional, yaitu pasal 34 mengenai wajib belajar bagi warga negara Indonesia (Komnasham, 2015).

Program wajib belajar yang telah dilaksanakan oleh pemerintah adalah wajib belajar sembilan tahun. Di Indonesia, setiap warga negara berusia 7-15 tahun tahun wajib mengikuti pendidikan dasar, yakni Sekolah Dasar/sederajat enam tahun dan Sekolah Menengah Pertama/ sederajat tiga tahun (Kemdiknas, 2012). Adanya program wajib belajar sembilan tahun yang ditetapkan oleh pemerintah, memberikan kesempatan pada anak-anak di Indonesia untuk dapat bersekolah hingga ke tingkat SMP. Jika anak-anak mampu menamatkan pendidikan menengah pertama, maka anak-anak tersebut memiliki kesempatan untuk melanjutkan pada jenjang pendidikan Sekolah Menengah Atas (SMA) dan memiliki tambahan wawasan yang lebih luas.
Sejak tanggal 25 Juni 2013 telah diluncurkan Program Pendidikan Menengah Universal (PMU) oleh Menteri Pendidikan dan Kebudayaan yang menjabat pada saat itu yaitu Mohammad Nuh. Program tersebut merupakan program rintisan wajib belajar 12 tahun yang merupakan kelanjutan dari program wajib belajar sembilan tahun. Program PMU lebih mendorong masyarakat untuk melanjutkan pendidikan hingga tingkat SMA (Sindonews, 2013). Adanya program wajib belajar 12 tahun dapat membuka kesempatan anak-anak untuk mengenyam pendidikan ke jenjang yang lebih tinggi bahkan hingga tingkat perguruan tinggi. Dewasa ini orang-orang mulai banyak belajar hingga jenjang perguruan tinggi. Menurut data Badan Pusat Statistik (BPS) Provinsi Bali pada tahun 2011 persentase kelulusan untuk jenjang perguruan tinggi sebanyak 6,68\%, pada tahun 2012 terjadi peningkatan menjadi 7,54\% dan pada tahun 2013 sebesar 7,13\% (Badan Pusat Statistik Provinsi Bali, 2014). Hal ini membuktikan bahwa masyarakat sudah mulai mengetahui akan pentingnya pendidikan

Pendidikan dan pengajaran merupakan hal yang penting dalam pembelajaran. Salah satu cara yang dapat meningkatkan standar pendidikan adalah dengan metode belajar yang tepat. Indonesia memiliki beberapa metode pembelajaran seperti pembelajaran teacher centered yaitu guru sebagai sosok yang dominan dalam proses pembelajaran dan siswa sebagai penerima informasi sehingga interaksi belajarmengajar lebih berpusat pada guru. Saat ini sedang dikembangkan metode belajar student centered yaitu pembelajaran yang berpusat pada siswa itu sendiri dan guru hanya sebagai fasilitator. Salah satu inti dari metode student centered adalah Small Group Discussion (SGD) atau model diskusi kelompok kecil. Menurut Slavin (2008) diskusi kelompok kecil (small group discussion) merupakan diskusi yang dilakukan dalam kelompok-kelompok yang beranggotakan empat sampai enam orang siswa yang bekerja untuk mendiskusikan topik tertentu.

Hasil survey awal yang dilakukan pada bulan Januari 2015 menunjukkan bahwa metode diskusi kelompok sudah diterapkan di Sekolah Dasar (SD) bahkan sampai di perguruan tinggi di Indonesia, khususnya Fakultas Kedokteran. Fakultas Kedokteran Universitas Indonesia, Universitas Gadjah Mada, Universitas Tarumanegara, Universitas Udayana, Universitas Warmadewa, bahkan beberapa SD, SMP, SMA mulai menerapkan student centered dengan porsi jam diskusi yang bervariasi.

Fakultas Kedokteran Universitas Udayana menerapkan sistem pembelajaran Student Center yaitu pembelajaran yang ada berpusat pada mahasiswa itu sendiri. Program Studi Pendidikan Dokter (PSPD) Fakultas Kedokteran Universitas Udayana saat ini sudah menerapkan konsep Problem Based Learning (PBL) dalam melaksanakan kurikulumnya sejak blok Studium Generale di semester I 
(hmkufkunud, 2011). PBL merupakan metode pembelajaran bagi peserta didik yang sejak awal dihadapkan pada suatu masalah, kemudian diikuti oleh proses pencarian informasi yang bersifat student centered. Salah satu sarana dari PBL adalah SGD. SGD adalah metode belajar dalam bentuk diskusi yang diikuti oleh mahasiswa dengan jumlah anggota antara 10 sampai 13 orang. SGD biasanya dilaksanakan selama 90 menit dan diawasi oleh seorang fasilitator yang merupakan dosen PSPD Fakultas Kedokteran Universitas Udayana.

Sebelum memulai SGD mahasiswa PSPD menerima lecture di dalam kelas terlebih dahulu, lecture adalah kuliah untuk memperkenalkan materi dan membuka wawasan keilmuan. Lecture diberikan oleh dosen selama 60 menit untuk membahas materi perkuliahan. Selanjutnya setelah melakukan lecture, mahasiswa PSPD diberikan kesempatan untuk melakukan individual learning. Individual learning merupakan proses belajar yang dilakukan mahasiswa secara sendirisendiri untuk mengembangkan dan meningkatkan proses belajar mandirinya. Individual learning biasanya berdurasi selama 90 menit. Saat melakukan individual learning, mahasiswa memanfaatkannya mencari materi tambahan untuk perkuliahan serta mencari tambahan materi untuk menjawab learning task yang nantinya akan didiskusikan dengan kelompok SGD setelah melakukan individual learning. SGD dilakukan di ruangan-ruangan SGD yang telah disiapkan dan berlangsung selama 90 menit. Saat melakukan SGD tersebut mahasiswa berdiskusi mengenai learning task pada hari itu. SGD digunakan untuk mendiskusikan, bertukar pendapat dan bersama-sama mencari jawaban dari learning task dengan teman satu kelompok. Saat melakukan diskusi di dalam ruangan SGD, mahasiswa akan difasilitasi oleh seorang dosen. Jika mahasiswa kurang paham dengan materi, mahasiswa dapat menanyakan kepada fasilitatornya. Selesai melakukan diskusi di ruangan SGD, mahasiswa akan kembali ke kelas untuk melakukan plenary session. Plenary session merupakan kegiatan yang dilakukan setelah diskusi kelompok berakhir untuk memberikan arahan tentang kesimpulan dalam diskusi kelompok yang belum mendapat kesepakatan di diskusi kelompok. Plenary session berlangsung selama 60 menit. Setiap kelompok mempresentasikan hasil diskusi yang dilakukan selama SGD.

Saat melakukan SGD tentunya ada tugas-tugas serta kasus-kasus yang diberikan oleh dosen dan harus dikerjakan serta membutuhkan kerja sama kelompok dalam satu SGD. Hasil pengamatan yang dilakukan terhadap SGD mahasiswa PSPD diperoleh hasil bahwa ada masalah dalam pengumpulan tugas akhir yaitu learning task yang telah dibagi antar anggota SGD, berupa kurangnya koordinasi, beberapa individu terlambat mengumpulkan bagian tugasnya, dan beberapa anggota kelompok sulit dihubungi.

Berita harian balipost yang ditulis oleh I Gusti Bagus Semarayadnya pada 6 Oktober 2006 menyebutkan dalam proses pendidikan sistem pendidikan cara belajar siswa aktif (CBSA) dapat diterapkan dengan membentuk kelompokkelompok belajar. Dari kelompok-kelompok belajar bisa mengurangi keharusan membeli buku. Diskusi kelompok mengajarkan pada siswa untuk melatih bekerja sama dalam satu tim, berdiskusi, mengeluarkan pendapat sendiri dan belajar berargumentasi, meningkatkan kepercayaan diri sehingga siswa tidak hanya menerima materi dari apa yang disajikan dalam buku cetakan (Semarayadnya, 2006).

Diskusi kelompok dibutuhkan oleh mahasiswa karena dalam kehidupan sehari-hari baik dalam lingkungan keluarga atau masyarakat tentunya membutuhkan diskusi untuk mencapai suatu kesepakatan, sehingga dari diskusi kelompok di kampus mahasiswa dapat belajar untuk mengungkapkan pendapat mereka. Menurut Amin dan Eng (2003), belajar merupakan kegiatan sosial yang berlangsung melalui kolaborasi dan interaksi. Metode kelompok kecil adalah salah satu cara untuk pembelajaran aktif dan kolaboratif. Amin dan Eng menambahkan pembentukan kelompok kecil menumbuhkan tanggung jawab bersama dan kerja tim dan membawa keahlian individu ke dalam kelompok. Oleh karena itu, kelompok kecil mampu melaksanakan pekerjaan lebih sulit dan rumit yang tidak akan mungkin dilakukan dengan bekerja sendiri. Menurut Amin dan Eng (2003), pembentukan kelompok kecil memiliki beberapa keuntungan seperti produksi kualitas kerja yang lebih tinggi, pengambilan keputusan yang lebih baik dari pada keputusan individu, dapat melakukan tugas-tugas yang lebih rumit, dan dapat belajar dari anggota kelompok lainnya.

Diskusi kelompok memiliki beberapa kegunaan dalam proses belajar seperti memberi kesempatan kepada mahasiswa untuk menyalurkan kemampuannya, membantu mahasiswa untuk belajar berpikir kritis, dan mengembangkan motivasi untuk belajar (Hasibuan \& Moediono 1999). Jika anggota SGD tidak merasa puas, nyaman dan diuntungkan maka proses SGD tidak akan berjalan dengan baik. Makmun (2007), mengungkapkan bahwa metode diskusi juga memiliki beberapa manfaat seperti memupuk semangat kerja sama dalam memecahkan masalah yang dihadapi melalui proses berpikir secara kelompok, menumbuhkan sikap saling memahami, serta menguatkan daya ingat.

Hasil riset yang dilakukan oleh (Sharan et al, 1984; Sharan dan Shancar, 1998 dalam Slavin 2008) menunjukkan bahwa diskusi kelompok kecil dapat meningkatkan pencapaian siswa dibandingkan dengan pelajaran konvensional jika siswa menyiapkan diri dengan baik untuk berkerja dalam kelompok kecil, serta tugas kelompok diorganisir dengan baik. Riset lainnya berpendapat bahwa diskusi kelompok kecil memiliki efek yang lebih besar pada pencapaian siswa jika siswa didorong untuk terlibat di dalam perdebatan bukan hanya untuk mencapai suatu kesepakatan (Johnson \& Johnson dalam Slavin 2008). Penelitian yang 
dilakukan oleh Afandi, dkk (2009) dengan judul "Effects of an additional small group discussion to cognitive achievement and retention in basic principles of bioethics teaching methods" menunjukkan bahwa metode pengajaran dengan tambahan diskusi kelompok kecil lebih baik daripada metode kuliah konvensional dalam meningkatkan pengetahuan dan retensi kaidah dasar bioetika. Dari beberapa penelitian tersebut membuktikan bahwa diskusi kelompok kecil membantu proses belajar siswa di sekolah.

Dalam proses SGD tentu ada interaksi antar anggota SGD. Jika para anggota SGD merasa nyaman dan puas dengan anggota SGD satu sama lainnya maka proses SGD akan berjalan dengan baik. Menurut Resbult dalam Taylor, Peplau dan Sears (2009), seseorang akan merasa puas jika suatu hubungan tersebut menguntungkan. Dalam melakukan SGD tentunya rasa puas dan nyaman sangat berpengaruh karena setiap melakukan SGD tentu ada saling mengeluarkan pendapat, gagasan, pembagian tugas antar kelompok yang dilakukan, sehingga membutuhkan kerja sama kelompok dengan teman satu kelompok. Kerja sama kelompok dalam memecahkan masalah sangat dibutuhkan dalam diskusi kelompok. Menurut Cremer dan Siregar (1993) agar mencapai hasil yang maksimal dalam kelompok kerja ada tiga syarat yang harus terpenuhi. Pertama, adanya pembagian kerja yang jelas dan sesuai. Kedua, bagaimana pemimpin mengatur jalannya diskusi dan gaya kepemimpinan apa yang digunakan. Ketiga, adanya komunikasi timbal balik antara anggota diskusi dengan pemimpin diskusi. Komunikasi yang baik antar anggota SGD akan lebih memperjelas informasi dan meningkatkan kerja sama kelompok.

Belajar dalam SGD diharapkan dapat meningkatkan kemampuan melakukan interaksi sosial, pengembangan keterampilan interpersonal, komunikasi, bekerja sama, keterampilan presentasi, bahkan dapat melatih sikap toleransi dan menerima adanya perpedaan pendapat. Adanya kepuasan dalam kerja sama kelompok menyebabkan proses SGD akan menjadi lebih efektif. Oleh karena itu kepuasan menjadi faktor yang penting. Saat melakukan SGD akan ada interaksi antara anggota kelompok, sementara itu kualitas interaksi dipengaruhi oleh kecerdasan sosial anggota kelompok. Individu yang memiliki kecerdasan sosial yang baik akan mudah berinteraksi dengan orang lain, memiliki kualitas komunikasi yang baik dan mampu bekerja sama dengan orang lain. Oleh karena itu, kecerdasan sosial yang dimiliki oleh individu akan berpengaruh terhadap kepuasan bekerja sama di dalam SGD. SGD yang efektif akan meningkatkan penguasaan mahasiswa pada materi tersebut dan memberikan pengaruh terhadap prestasi akademik. Sebaliknya jika mahasiswa tidak merasa nyaman dengan proses serta interaksi dengan anggota SGD, maka proses pembelajaran tidak akan berjalan efektif sehinga prestasi juga tidak akan optimal.
Berdasarkan uraian tentang proses SGD yang telah dijelaskan sebelumnya, salah satu faktor yang memengaruhi kerja sama kelompok antar anggota SGD adalah kecerdasan sosial pada anggota kelompok. Menurut Gardner (2003), kecerdasan interpersonal atau kecerdasan sosial merupakan kemampuan inti untuk mengendalikan perbedaan. Secara khusus perbedaan besar dalam suasana hati, temperamen, motivasi, dan kehendak.

Hasil penelitian studi kasus yang telah dilakukan pada bulan September 2014 dengan judul "Pengaruh Kecerdasan intelektual dan kecerdasan sosial terhadap prestasi belajar anak sd yang bersekolah sambil bekerja, bersekolah reguler, dan homeschooling" didapatkan hasil bahwa anak yang memiliki kecerdasan intelektual yang tinggi dan kecerdasan sosial yang baik maka dapat berprestasi, berinteraksi dan bersosialisasi dengan baik terhadap temantemannya (Dewi, 2014). Hasil penelitian yang dilakukan oleh Muzayanah dan Dian (2008) dengan judul "Hubungan antara kecerdasan interpersonal dengan kepuasan kerja karyawan (Guru), didapatkan hasil bahwa adanya hubungan positif antara kecerdasan interpersonal dengan kepuasan kerja. Aspek-aspek kecerdasan sosial juga diungkapkan oleh Goleman (2007), salah satu aspeknya adalah penyelarasan. Penyelarasan adalah kemampuan untuk menyesuaikan diri dengan orang lain. Aspek tersebut dibutuhkan dalam melakukan kerja sama kelompok dalam SGD.

Berdasarkan pemaparan tersebut maka perlu diketahui secara lebih terukur keterkaitan kecerdasan sosial dengan kepuasan kerja sama kelompok di dalam SGD dan seberapa besar kepuasan mahasiswa terhadap kerja sama dalam SGD. Diharapkan penelitian ini dapat memberikan manfaat untuk pengembangan teori dan ilmu pengetahuan dalam bidang ilmu psikologi khususnya psikologi pendidikan, sosial, dan komunikasi terkait dengan kecerdasan sosial dan kepuasan dalam kerja sama kelompok. Manfaat praktis dari penelitian ini adalah bagi institusi pendidikan diharapkan hasil penelitian ini mampu memberikan sumbangan informasi untuk dijadikan pertimbangan cara pembelajaran student center learning yaitu metode SGD, sebagai salah satu metode pembelajaran untuk merangsang mahasiswa untuk lebih mampu mengembangan keterampilan interpersonal, komunikasi, keterampilan presentasi, dan sikap menghargai perbedaan pendapat di dalam kelompok SGD, sehingga mampu bekerja sama dengan baik dalam SGD. Serta hasil penelitian ini mampu memberikan sumbangan informasi tentang hubungan kecerdasan sosial dengan kepuasan kerja sama kelompok dalam SGD dan pentingnya kecerdasan sosial dalam kerja sama kelompok. Bagi mahasiswa hasil penelitian ini diharapkan dapat memberikan informasi kepada mahasiswa mengenai faktor-faktor pribadi yang harus dikembangkan untuk keberhasilan kerja sama kelompok dalam SGD, sehingga memudahkan mahasiswa dalam 
berinteraksi, bersosialisasi dan berkomunikasi dalam kelompok SGD. Bagi peneliti lain dapat digunakan sebagai gambaran khususnya mengenai kecerdasan sosial dan kepuasan kerja sama kelompok dalam SGD, dan dapat dijadikan sebagai bahan perbandingan untuk penelitian selanjutnya.

\section{METODE PENELITIAN}

\section{Variabel dan Definisi Operasional}

Variabel bebas dalam penelitian ini adalah kecerdasan social sedangkan variabel terikat dalam penelitian ini adalah kepuasan kerja sama kelompok. Adapun definisi operasional dari masing-masing variabel penelitian ialah sebagai berikut:

1. Kecerdasan sosial adalah keterampilan yang dimiliki oleh individu untuk memahami orang lain, memberikan motivasi, serta untuk bekerja sama dengan orang lain. Kecerdasan sosial diukur dengan skala Kecerdasan Sosial yang disusun berdasarkan delapan aspek kecerdasan sosial dari Goleman (2007), yaitu empati dasar, penyelarasan, ketepatan empati, pengertian sosial, sinkroni, presentasi diri, pengaruh, kepedulian. Skor total aitem yang diperoleh menunjukkan kecerdasan sosial yang dimiliki subjek. Semakin tinggi skor yang diperoleh maka semakin tinggi kecerdasan sosial subjek penelitian.

2. Kepuasan kerja sama kelompok dalam SGD adalah perasaan positif yang dirasakan individu dalam berinteraksi dan bekerja sama untuk mencapai tujuan bersama di dalam diskusi kelompok SGD yang terdiri dari 10 sampai 13 orang mahasiswa. Kepuasan kerja sama kelompok diukur dengan skala Kepuasan Kerja Sama Kelompok yang disusun berdasarkan gabungan dua teori dari teori Cremer dan Siregar (1993) serta teori Kreitner dan Kinicki (2014). Tiga aspek kerja sama kelompok dari Cremer dan Siregar (1993) yaitu pembagian kerja yang jelas, gaya kepemimpinan yang diterapkan, komunikasi timbal balik di antara anggota kelompok dan pemimpin. Serta empat faktor yang memengaruhi kepuasan kerja dari Kreitner dan Kinicki (2014) yaitu pemenuhan kebutuhan, perbedaan, pencapaian nilai, keadilan. Skor total aitem yang diperoleh menunjukkan kepuasan kerja sama kelompok yang dimiliki subjek. Semakin tinggi skor yang diperoleh maka semakin tinggi kepuasan kerja sama kelompok yang dialami subjek penelitian.

\section{Subjek Penelitian}

Populasi dalam penelitian ini adalah mahasiswa Program Studi Pendidikan Dokter (PSPD) Fakultas Kedokteran Universitas Udayana yang masih aktif melakukan SGD yang berjumlah 773 orang. Setiap angkatan terdiri dari dua kelas yaitu kelas reguler dan kelas internasional. Sampel yang digunakan pada penelitian ini adalah mahasiswa Program Studi Kedokteran Umum (PSPD) Fakultas Kedokteran Universitas Udayana angkatan 2012, 2013, dan 2014. Teknik pengambilan sampel untuk penelitian ini adalah cluster random sampling, yaitu teknik sampling dengan cara melakukan randomisasi terhadap kelompok, bukan terhadap subjek secara individual (Azwar, 2013). Teknik ini dipilih agar setiap kelas terwakili sebagai sampel. Cara pengambilan sampel pada penelitian ini adalah dengan cara merandom SGD di PSPD. Jumlah subjek dalam penelitian ini adalah 274 orang.

\section{Tempat Penelitian}

Proses pengambilan data dilakukan di PSPD Fakultas Kedokteran Universitas Udayana, di ruang SGD pada bulan Mei 2015.

\section{Alat Ukur}

Alat ukur yang digunakan dalam penelitian ini adalah dua skala yaitu skala Kecerdasan Sosial dan skala Kepuasan Kerjasama Kelompok. Skala Kecerdasan Sosial disusun berdasarkan delapan aspek kecerdasan sosial dari Goleman (2007), dan skala Kepuasan Kerjasama Kelompok disusun berdasarkan gabungan dua teori dari teori Cremer dan Siregar (1993) serta teori Kreitner dan Kinicki (2014). Skala Kecerdasan Sosial terdiri dari 30 aitem pernyataan dan skala Kepuasan Kerja Sama Kelompok terdiri dari 45 pernyataan. Skala Kecerdasan Sosial dan Kepuasan Kerja Sama Kelompok disusun dalam bentuk pernyataan favorable dan unfavorable yang diberi skor mulai dari 1 sampai 4. Pada skala Kecerdasan Sosial dan Kepuasan Kerja Sama Kelompok terdapat 4 respon jawaban, yaitu sangat setuju (SS), setuju (S), tidak setuju (TS), dan sangat tidak setuju (STS). Pada pernyataan dalam aitem favorable jawaban sangat setuju (SS) diberi skor 4, setuju (S) diberi skor 3, tidak setuju (TS) diberi skor 2, dan sangat tidak setuju (STS) diberi skor 1. Sedangkan dalam pernyataan dalam aitem unfavorable jawaban sangat setuju (SS) diberi skor 1, setuju (S) diberi skor 2, tidak setuju (TS) diberi skor 3, dan sangat tidak setuju (STS) diberi skor 4.

Pada pengujian validitas skala Kecerdasan Sosial koefisien korelasi aitem total mempunyai nilai dari 0,2640,508. Hasil reliabilitas skala Kecerdasan Sosial dengan menggunakan Cronbach Alpha $(\alpha)$ adalah sebesar 0,871 . Alpha $(\alpha)$ sebesar 0,871 menunjukkan bahwa $87,1 \%$ variasi skor subjek pada skala ini adalah skor murni. Hasil tersebut menggambarkan bahwa skala Kecerdasan Sosial dapat digunakan untuk mengukur kecerdasan sosial.

Pada pengujian validitas skala Kepuasan Kerja Sama Kelompok koefisien korelasi aitem total mempunyai nilai dari 
0,309-0,680. Hasil uji reliabilitas skala Kepuasan Kerja sama Kelompok dengan menggunakan Cronbach Alpha $(\alpha)$ adalah sebesar 0,938. Alpha $(\alpha)$ sebesar 0,938 menunjukkan 93,8\% variasi skor subjek pada skala ini adalah skor murni. Hasil tersebut menggambarkan skala Kepuasan Kerja sama Kelompok dapat digunakan untuk mengukur kepuasan kerja sama kelompok.

\section{Teknik Analisis Data}

Teknik analisis yang digunakan untuk dapat menguji hipotesis dalam penelitian ini adalah analisis korelasi pearson product moment. Teknik analisis pearson product moment merupakan teknik statistik parametrik. Analisis ini digunakan untuk menguji hipotesis hubungan antara satu variabel bebas dengan satu variabel tergantung. Analisis dilakukan dengan bantuan perangkat lunak SPSS versi 15.00.

\section{HASIL PENELITIAN}

\section{Karakteristik Subjek}

Diketahui bahwa 274 subjek penelitian tersebar dari angkatan 2012 sampai 2014. Mayoritas subjek adalah angkatan 2013. Angkatan 2012 lebih sedikit dibandingkan angkatan 2013 dan 2014 karena jumlah SGD 2013 lebih banyak, serta kuesioner yang disebarkan pada angkatan 2012 lebih banyak tidak kembali dibandingkan dengan angkatan lainnya. Deskripsi Data Penelitian

Pada rangkuman data deskripsi pada tabel 1 , terlihat bahwa perbedaan mean empiris dan mean teoritis pada variabel kecerdasan sosial sebesar 10,91. Mean empiris lebih tinggi dari mean teoritis, menunjukkan bahwa terdapat perbedaan antara mean empiris dan mean teoritis pada kecerdasan sosial. Rentang skor subjek penelitian antara 69 sampai 110 yang berdasarkan penyebaran frekuensi , 94,9\% subjek berada diatas mean teoritis.

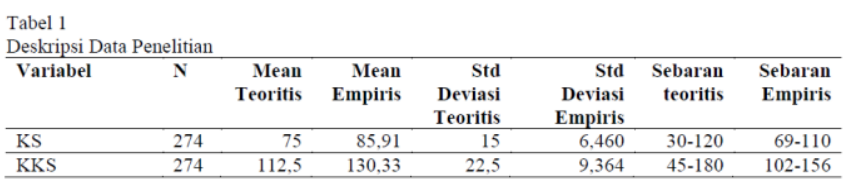

Keterangan :

KS : Kecerdasan Sosial, KKS : Kepuasan Kerja sama Kelompok

Perbedaan mean empiris dan mean teoritis pada variable kepuasan kerja sama kelompok sebesar 17,83. Mean empiris lebih tinggi dari mean teoritis, menunjukkan bahwa terdapat perbedaan antara mean empiris dan mean teoritis pada kepuasan kerja sama kelompok. Rentang skor subjek penelitian antara 102 sampai 156 dan 96\% subjek berada diatas mean teoritis.

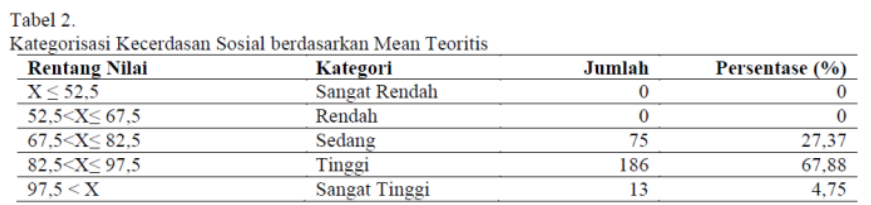

Pada tabel 2 tersebut, katagorisasi kecerdasan sosial berdasarkan mean teoritis didapatkan hasil bahwa persentase subjek dengan kecerdasan sosial Sangat rendah sebesar 0\%, Rendah sebesar 0\%, katagori Sedang sebesar 27,37\%, Tinggi sebesar 67,88\%, dan Sangat tinggi sebesar 4,75\%. Oleh karena itu, dapat disimpulkan bahwa mayoritas subjek tergolong dalam kategorisasi kecerdasan sosial yang tinggi.

Tabel 3 .

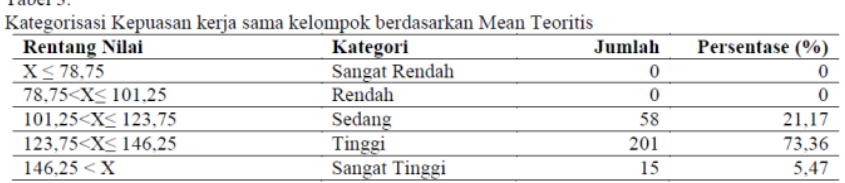

Pada tabel 3 tersebut, katagorisasi kepuasan kerja sama kelompok berdasarkan mean teoritis didapatkan hasil bahwa persentase subjek dengan kepuasan kerja sama kelompok Sangat rendah sebesar 0\%, Rendah sebesar 0\%, katagori Sedang sebesar 21,17\%, Tinggi sebesar 73,36\%, dan Sangat Tinggi sebesar 5,47\%. Dengan demikian dapat disimpulkan bahwa mayoritas subjek tergolong dalam kategorisasi kepuasan kerja sama kelompok tinggi .

\section{Uji Asumsi}

Pada tabel 4 terlihat bahwa variabel kecerdasan sosial memiliki nilai Kolmogorof-Smirnov sebesar 1,121 dengan signifikansi sebesar $0,162 \quad(\mathrm{p}>0,05)$. Nilai tersebut menunjukkan bahwa data pada variabel kecerdasan sosial memiliki distribusi yang normal. Data dari variabel kepuasan kerja sama kelompok memiliki nilai Kolmogorof-Smirnov sebesar 1,309 dengan signifikansi sebesar 0,065 ( $\mathrm{p}>0,05)$. Nilai tersebut menunjukkan bahwa data pada variabel kepuasan kerja sama kelompok memiliki distribusi yang normal.

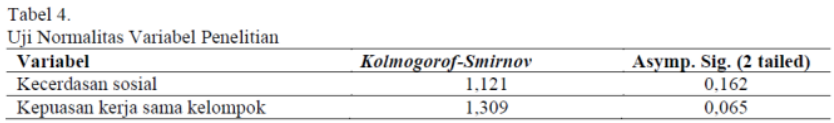

Pada tabel 5 terlihat bahwa nilai signifikansi liniarity pada kedua variabel lebih kecil dari 0,05 yaitu sebesar 0,000. Maka dapat disimpulkan bahwa terdapat hubungan yang linier antara variabel kecerdasan sosial dengan kepuasan kerja sama kelompok. 


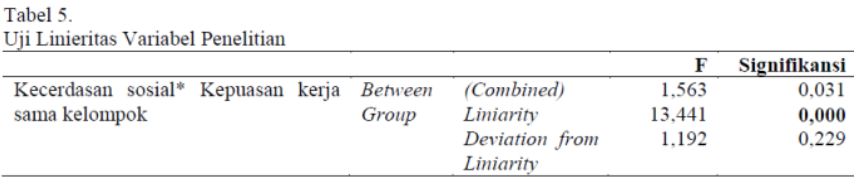

\section{Uji Hipotesis}

Pada penelitian ini akan dilakukan uji hipotesis dengan menggunakan uji analisis korelasi Pearson Product Moment.

\begin{tabular}{lllc}
$\begin{array}{l}\text { Tabel 6. } \\
\text { Hasil Uji korelasi Pearson Product Moment }\end{array}$ & Sig.(2-tailed) \\
\hline $\begin{array}{l}\text { Pearson } \\
\text { correlation }\end{array}$ & KS & KKS & 0,000 \\
\hline KS & 1 & 0,215 & 0,000 \\
\hline KKS & 0,215 & 1 & \\
\hline
\end{tabular}

Keterangan :

KS : Kecerdasan Sosial, KKS : Kepuasan Kerja sama Kelompok

Hasil analisis korelasi Pearson Product Moment menunjukan koefisien korelasi sebesar 0,215 dan signifikansi sebesar 0,000 $(\mathrm{p}<0,05)$. Hal tersebut menunujukkan bahwa kecerdasan sosial memiliki korelasi yang signifikan terhadap kepuasan kerja sama kelompok.

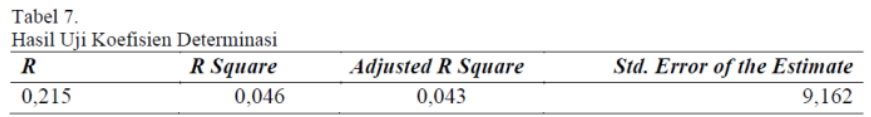

Pada tabel hasil uji koefisien determinasi diatas dihasilkan nilai $\mathrm{R}$ square 0,046. Artinya 4,6\% variabel kepuasan kerja sama kelompok dapat dijelaskan oleh variabel kecerdasan sosial, dan sebesar 95,4\% dapat dijelaskan oleh faktor lain.

\section{PEMBAHASAN DAN KESIMPULAN}

Berdasarkan hasil analisis terdapat hubungan yang signifikan antara kecerdasan sosial dengan kepuasan kerja sama kelompok pada peserta SGD di PSPD Fakultas Kedokteran (FK) Universitas Udayana (Unud). Semakin tinggi kecerdasan sosial maka semakin besar pula tingkat kepuasannya terhadap kerja sama kelompok.

Individu yang memiliki kecerdasan sosial yang tinggi maka mudah menjalin hubungan dengan orang lain, mudah berinteraksi dengan orang lain, bisa berempati terhadap orang lain sehingga memudahkan dalam bersosialisasi dengan orang lain, dapat menangkap emosi non verbal dari orang lain dan memiliki rasa peduli terhadap kebutuhan orang lain (Goleman, 2007). Hal tersebut sejalan dengan penelitian yang dilakukan oleh Muzayanah dan Dian (2008), yang menunjukkan bahwa terdapat hubungan signifikan antara kecerdasan interpersonal terhadap kepuasan kerja karyawan (guru). Hasil penelitian tersebut menunjukkan orang yang mempunyai kecerdasan sosial yang tinggi maka akan merasa puas dalam bekerja meskipun mendapatkan fasilitas yang kurang, dikarenakan orang yang memiliki kercerdasan sosial yang tinggi suka berteman dan bekerja sama, memiliki sikap empati, mampu berkomunikasi dengan baik dan mampu bersosialisasi dengan baik. Hal ini diperkuat dengan hasil wawancara dengan salah satu subjek menyatakan bahwa, walaupun fasilitas ruangan SGD seperti pendingin ruangan mati, subjek tetap melakukan SGD dengan anggota kelompoknya.

Penelitian yang dilakukan oleh Sholihah, Karyanto dan Sugiharto (2012), menunjukkan semakin tinggi kecerdasan interpersonal yang dimiliki oleh siswa, maka semakin tinggi pula kecenderungan siswa tersebut untuk memiliki hasil belajar biologi yang tinggi. Oleh karena itu, individu yang memiliki kecerdasan sosial yang baik akan mudah bersosialiasi dan mampu menyeleraskan diri dengan kelompok sosial di dalam kelas (Goleman, 2007), sehingga mampu mendorong individu untuk berprestasi.

Kecerdasan sosial terdiri dari delapan aspek, masing-masing aspek memiliki peranan dalam proses interaksi sosial dengan anggota kelompok SGD. Hubungan kecerdasan sosial dengan kepuasan kerja sama kelompok dalam penelitian ini dapat dijelaskan dengan penjabaran berikut ini melalui aspek kecerdasan sosial.

Aspek pertama dari kecerdasan sosial, yaitu empati dasar dengan indikator dapat menangkap ekspresi emosi orang lain. Individu yang memiliki kecerdasan sosial yang tinggi maka akan mudah menangkap perubahan ekspresi dari lawan bicaranya. Menurut Goleman (2007), empati dasar merupakan kemampuan merasakan emosi orang lain. Empati dasar menunjukkan perasaan isyarat-isyarat nonverbal dapat dimengerti. Individu dengan kemampuan ini dapat menangkap emosi yang muncul dari mimik wajah seseorang sehingga dimengerti tujuannya. Individu dengan kecerdasan sosial yang baik akan bisa membaca emosi yang dirasakan oleh lawan bicaranya. Kemampuan membaca ekspresi emosi ini dapat digunakan untuk menyesuiakan diri dengan keadaan lawan bicara, sehingga lebih memudahkan dalam bersikap dan memilih topik pembicaraan.

Aspek kedua kecerdasan sosial, yaitu penyelarasan dengan indikator mudah menyesuaikan diri dengan orang lain. Menurut Ivancevich, dkk (2006), dalam pembentukan kelompok terdapat tahapan pembentukan norma. Tahapan ini ditandai dengan adanya kerja sama dan kekompakan. Tahap ini juga merupakan tahap saat kohesivitas kelompok mulai berkembang secara signifikan. Pada tahap ini mulai muncul ketertarikan, komitmen, serta perasaan terhadap identitas kelompok dan pertemanan di dalamnya. Saat bekerja sama di dalam kelompok tentunya akan ada interaksi antar anggota kelompok. Menurut Goleman (2007), penyelarasan yaitu anggota kelompok menyesuikan diri dengan anggotanya serta memberikan perhatian terhadap anggota. Jika individu dalam kelompok memiliki kecerdasan sosial yang baik maka akan 
memudahkan individu tersebut dalam berkomitmen dan menjalin pertemanan sehingga akan terbentuk kerja sama yang baik dengan anggota kelompok dan menyebabkan timbulnya rasa puas terhadap kerja sama kelompok di dalamnya.

Aspek ketiga dari kecerdasan sosial, yaitu ketepatan empati, memiliki indikator seperti dapat memahami pikiran, perasaan, dan maksud orang lain. Devito (1997), mengungkapkan orang yang empati mampu memahami motivasi dan pengalaman orang lain, perasaan dan sikap orang lain, serta mampu memahami harapan dan keinginan orang lain. Menurut Goleman (2001), individu yang empati adalah individu yang mampu menyesuaikan dengan tuntutan orang lain, memiliki ketenangan dan mampu mengelola emosi. Jika di dalam SGD masing-masing anggota kelompok dapat memahami apa yang dimaksudkan oleh teman kelompoknya, memahami perasaan dan pemikiran kelompok, maka kerja sama kelompok akan semakin erat dan menimbulkan rasa puas terhadap kerja sama kelompok tersebut.

Aspek keempat dari kecerdasan sosial, yaitu pengertian sosial dengan indikator seperti memiliki pengetahuan mengenai lingkungan sosial dan dapat menempatkan diri dengan baik dalam situasi sosial. Mahasiswa PSPD FK Unud akan selalu berhubungan dengan orang lain termasuk teman, para dosen di tempat kuliah, serta masyarakat. Buzan (2009) menyatakan bahwa kecerdasan sosial merupakan sejauh mana individu bergaul dan berhubungan dengan orang lain di sekitarnya. Mahasiswa akan bergaul dengan beragam orang, sehingga saat penempatan kelompok SGD belum tentu mahasiswa tersebut akan mendapatkan teman dengan kepribadian yang sama. Dalam proses SGD, mahasiswa akan belajar bertukar pikiran, saling bekerja sama dan mengeluarkan pendapat dalam pemecahan kasus yang telah disediakan. Semarayadnya (2006), yang menyatakan bahwa dalam proses pendidikan, sistem Pendidikan Cara Belajar Siswa Aktif (CBSA) dapat diterapkan dengan membentuk kelompok-kelompok belajar. Diskusi kelompok mengajarkan pada siswa untuk melatih bekerja sama dalam satu tim, berdiskusi, mengeluarkan pendapat sendiri dan belajar berargumentasi, meningkatkan kepercayaan diri sehingga siswa tidak hanya menerima materi dari apa yang disajikan dalam buku cetakan. Oleh karena itu, mahasiswa yang mempunyai kecerdasan sosial yang tinggi akan mampu menempatkan diri dimana pun berada, sehingga mampu bersosialisasi dengan baik dengan semua orang, dan mampu bekerja sama dengan baik dengan kelompoknya.

Aspek kelima kecerdasan sosial, yaitu sinkroni, memiliki indikator seperti dapat berinteraksi dengan baik melalui bahasa nonverbal (gerakan tubuh, ekspresi wajah, dan pandangan mata), serta dapat memahami bahasa nonverbal orang lain. Sinkroni adalah perilaku penyesuaian diri yang bertujuan untuk penyelarasan kebersamaan dalam kelompok sosial di dalam kelas (Goleman, 2007). Individu yang memiliki kecerdasan sosial yang baik akan dapat menangkap dan berinteraksi melalui bahasa nonverbal dengan orang lain seperti gerakan tubuh, ekspresi wajah, dan pandangan mata (Goleman, 2007). Individu dalam kelompok saling berhubungan dan memiliki potensi untuk melakukan interaksi bersama-sama (Taylor, dkk, 2009). Jika mahasiswa memiliki sinkroni yang baik, maka akan mudah memahami keadaan anggota kelompoknya di dalam SGD. Menurut Resbult dalam Taylor, dkk (2009), seseorang akan merasa puas jika suatu hubungan tersebut menguntungkan. Saat melakukan SGD rasa puas dan nyaman sangat berpengaruh, karena ketika melakukan SGD akan ada saling mengeluarkan pendapat, gagasan, pembagian tugas antar kelompok yang dilakukan, sehingga membutuhkan kerja sama kelompok dengan teman satu kelompok. Jika anggota SGD tidak merasa puas, nyaman dan diuntungkan maka proses SGD tidak akan berjalan dengan baik.

Aspek keenam dari kecerdasan sosial, yaitu presentasi diri dengan indikator menampilkan diri dengan efektif ketika berinteraksi dengan orang lain. Saat berinteraksi dalam kelompok sosial, individu ingin diterima di dalam kelompok tersebut. Menurut Taylor, dkk (2009) presentasi diri mengacu pada usaha untuk bertindak dengan cara tertentu yang menciptakan kesan khusus tentang diri. Individu yang memiliki kecerdasan sosial yang baik, maka akan mampu memberikan kesan yang baik tentang dirinya kepada teman kelompok. Adanya kesan yang baik menyebabkan individu tersebut mudah diterima di dalam kelompok, sehingga memudahkan dalam bekerja sama dengan anggota kelompok dan akan menimbulkan rasa puas terhadap kerja sama dalam kelompok.

Aspek ketujuh kecerdasan sosial, yaitu pengaruh dengan indikator dapat memengaruhi orang lain untuk berbuat sesuatu. Individu dengan kecerdasan sosial yang tinggi akan mudah untuk memengaruhi orang lain untuk berbuat sesuatu. Menurut Myers (2009), kelompok merupakan dua orang atau lebih yang lebih saling berinteraksi, memengaruhi satu sama lain. Individu di dalam kelompok yang memiliki kecerdasan sosial yang baik, akan mampu untuk memengaruhi teman kelompoknya untuk mengubah pendapat atau berbuat sesuatu. Menurut Kreitner dan Kinicki (2014), salah faktor yang memengaruhi kepuasan dalam bekerja adalah perbedaan. Model ini menyatakan bahwa kepuasan merupakan suatu hasil memenuhi harapan. Pemenuhan harapan mencerminkan perbedaan antara apa yang diharapkan dan yang diperoleh individu dari pekerjaannya. Jika harapan lebih besar daripada yang diterima, maka individu tidak puas. Sebaliknya individu akan puas apabila menerima manfaat di atas harapan. Oleh karena itu, individu yang mampu memberikan pengaruh terhadap teman kelompoknya, dan individu lain menerima serta merasa harapannya terpenuhi, maka individu merasa puas dengan kelompoknya. 
Aspek kedelapan dari kecerdasan sosial, yaitu kepedulian dengan indikator peduli terhadap kebutuhan orang lain. Seseorang yang memiliki kecerdasan sosial yang tinggi, maka akan memiliki sikap peduli terhadap orang lain dan kelompoknya. Menurut Goleman (2007) kepedulian merupakan peduli terhadap kebutuhan orang lain dan melakukan tindakan yang sesuai dengan hal tersebut. Hal ini diperkuat dengan hasil wawancara dari salah satu subjek yang menyebutkan bahwa, subjek merasa puas dengan kerja sama dalam kelompok SGD nya karena anggota di dalam kelompok tersebut memiliki kepedulian terhadap anggota lainnya. Subjek bercerita bahwa ketika salah satu anggota SGD sedang sedih, maka anggota lainnya langsung menghibur teman yang sedih tersebut dengan cara membuat lelucon yang lucu, bahkan setelah pulang kuliah anggota SGD juga mengajak teman yang sedang sedih untuk makan bersama.

Mayoritas kecerdasan sosial mahasiswa PSPD FK Unud berada dalam katagori kecerdasan sosial yang tinggi. Kecerdasan sosial yang tinggi menunjukkan bahwa mahasiswa PSPD FK Unud mampu bersosialisasi dan berinteraksi dengan baik lingkungan di sekitarnya. Mayoritas kepuasan kerja sama kelompok mahasiswa PSPD FK Unud memiliki kepuasan kerja sama kelompok tinggi. Kepuasan kerja sama kelompok tinggi menunjukkan bahwa mahasiswa PSPD FK Unud merasa puas terhadap kerja sama kelompok di dalam SGD.

Kecerdasan sosial mahasiswa PSPD FK Unud tergolong tinggi dapat disebabkan oleh mahasiswa mampu berinteraksi dengan baik dalam kelompoknya. Menurut Gardner (2003), kecerdasan interpersonal atau kecerdasan sosial merupakan kemampuan inti untuk mengendalikan perbedaan besar dalam suasana hati, temperamen, motivasi, dan kehendak. Dalam interaksi SGD, individu yang memiliki kecerdasan sosial yang tinggi akan mampu membaca emosi orang lain melalui ekspresi wajah, walaupun teman tersebut tidak mengungkapkannya. Individu yang memiliki kecerdasan sosial yang tinggi akan bisa meredakan konflik yang terjadi di dalam kelompoknya, serta mudah memahami maksud orang lain dalam kelompok. Individu yang memiliki kecerdasan sosial yang baik juga mampu berkomunikasi dengan baik dengan orang lain. Hal tersebut sesuai dengan hasil penelitian yang dilakukan oleh Gusliza (2013), yang menunjukkan bahwa semakin baik komunikasi interpersonal maka akan semakin tinggi kepuasan kerja. Adanya hubungan pertemanan yang baik dan komunikasi yang baik maka akan membantu mahasiswa dalam proses pemahaman materi di tempat kuliah, maka jika individu memiliki pertemanan dan hubungan sosial yang baik dengan teman-temannya maka akan lebih menimbulkan rasa nyaman dan memudahkan individu untuk saling berdiskusi terkait masalah perkuliahan ataupun permasalahan pribadi.

Kepuasan kerja sama kelompok dalam SGD tergolong tinggi karena dari hasil wawancara dengan subjek yang memiliki kepuasan yang tinggi, subjek merasa puas dengan kerja sama kelompok SGD nya. Subjek mengatakan bahwa jumlah jenis kelamin dalam SGD seimbang dan banyak ada beragam kepribadian sehingga saling melengkapi dan membuat rasa nyaman antar anggota SGD. Teman-teman dalam kelompok SGD mau membantu jika subjek belum memahami materi. Pembagian tugas dalam kelompok dilakukan lewat undian, jika ada anggota yang mendapatkan bagian tugas yang sulit maka anggota yang lain mau membantu. Subjek mengatakan bahwa ketua kelompok bersikap adil dengan para anggota, ketua kelompok dapat membuat suasana SGD lebih kondusif sehingga para anggota SGD merasa nyaman dan senang. Jika terjadi konflik dalam SGD, maka permasalahan tersebut akan diselesaikan pada hari itu juga. Teman-teman satu kelompok mau mendengarkan pendapat anggota lain bahkan mau mendengarkan permasalahan pribadi subjek. Subjek mengatakan bahwa teman-teman kelompoknya memiliki kepedulian dengan anggota kelompok, seperti ketika ada teman yang ulang tahun maka akan dirayakan bersama-sama dalam SGD.

Menurut Kreitner dan Kinicki (2014) kepuasan merupakan tingkatan dalam seseorang menyukai pekerjaannya. Krietner dan Kinicki menyatakan bahwa seseorang bisa merasa cukup puas dengan salah satu aspek dalam pekerjaannya dan merasa kurang puas dengan satu atau beberapa aspek lainnya. Menurut (Cremer \& Siregar, 1993) agar mencapai hasil yang maksimal dalam kelompok kerja ada tiga syarat yang harus terpenuhi. Pertama, adanya pembagian kerja yang jelas dan sesuai. Kedua, bagaimana pemimpin mengatur jalannya diskusi dan gaya kepemimpinan apa yang digunakan. Ketiga adanya komunikasi timbal balik antara anggota diskusi dengan pemimpin diskusi. Adanya komunikasi yang baik antar anggota SGD akan lebih memperjelas informasi dan meningkatkan kerja sama tim. Kartono (2006) mengungkapkan bahwa seorang pemimpin yang mampu memenuhi harapan, keinginan, dan kebutuhan para anggota, maka anggota akan merasa puas.

Dari hasil wawancara didapatkan data bahwa dua orang subjek berada dalam kepuasan kerja sama kelompok yang tergolong sedang. Dari hasil wawancara kedua subjek mengatakan bahwa merasa kurang puas dengan kepemimpinan ketua kelompok dalam SGD. Hasil wawancara kedua subjek menunjukkan bahwa ketua SGD kurang memiliki sikap tegas sebagai pemimpin sehingga beberapa anggota yang mengambil alih untuk membantu pemimpin. Pemimpin cepat merasa panik sehingga anggota ikut menjadi panik dan khawatir dengan tugas serta ketua SGD jarang memberikan motivasi kepada anggota SGD. Menurut Cremer dan Siregar (1993) gaya kepemimpinan demokratis merupakan pimpinan kelompok mampu memotivasi para anggota agar mereka menghasilkan prestasi yang terbaik. Jika pemimpin SGD kurang mampu memberikan motivasi kepada 
anggota, maka anggota akan kurang menghasilkan pekerjaan yang maksimal. Salah satu tugas pemimpin dalam kelompok menurut Kartono (2006), pemimpin kelompok harus bersikap kritis dan rasional, yaitu pemimpin berani mengemukakan pendapat sendiri dan berani bersikap dan bertanggung jawab. Jika pemimpin tidak bersikap tegas, maka para anggota akan merasa kurang nyaman dengan pemimpin tersebut.

Adanya kepuasan dalam kerja sama kelompok, maka diskusi akan berjalan dengan baik sehingga SGD akan menjadi lebih efektif. SGD yang efektif akan memengaruhi proses belajar mahasiswa di dalamnya. Informasi tambahan diperoleh mahasiswa yang dibutuhkan dalam proses belajar. Serta akan meningkatkan pengetahuan mahasiswa pada meteri tersebut dan memberikan pengaruh terhadap prestasi akademik. Sebaliknya jika mahasiswa tidak merasa nyaman dengan anggota kelompok, adanya pembagian tugas yang tidak jelas, komunikasi yang kurang baik maka SGD tidak berjalan dengan efektif. Mahasiswa menjadi kurang suka untuk berdiskusi dan mengemukakan pendapat.

Dari pemaparan semua data dan analisis statistik diatas, maka tujuan dari penelitian ini telah mampu terpenuhi yaitu untuk mengetahui hubungan kecerdasan sosial dengan kepuasan kerja sama kelompok di dalam SGD.

Berdasarkan penelitian yang telah dilakukan dan hasil analisis data statistik dapat ditarik kesimpulan yaitu terdapat hubungan yang signifikan, namun lemah antara kecerdasan sosial dengan kepuasan kerja sama kelompok dalam SGD pada mahasiswa Program Studi Pendidikan Dokter Fakultas Kedokteran Universitas Udayana. Kecerdasan sosial memiliki hubungan yang positif dan searah dengan kepuasan kerjasama kelompok dalam SGD di Program Studi Pendidikan Dokter Fakultas Kedokteran Universitas Udayana. Semakin tinggi kecerdasan sosial maka semakin baik kepuasan kerja sama kelompok dalam SGD. Kecerdasan sosial dapat menjelaskan varian kepuasan kerja sama kelompok dalam SGD sebesar 4,6\%. Sebanyak $72,63 \%$ mahasiswa memiliki kecerdasan sosial diatas rata-rata dan $27,37 \%$ dibawah rata-rata. Sebanyak $78,83 \%$ mahasiswa memiliki kepuasan kerja sama kelompok ditas rata-rata dan $21,17 \%$ dibawah rata-rata.

Berdasarkan kesimpulan penelitian, maka diberikan saran kepada pihak-pihak terkait yaitu institusi pendidikan perlu mempertahankan metode belajar SGD karena metode belajar SGD hmendorong mahasiswa belajar untuk bekerja sama, berkomunkasi, dan bersosialisasi dalam kelompok, sehingga mahasiswa akan lebih mampu bekerja sama dan bersosialisasi dalam masyarakat dan lingkungan sosial di luar kampus. Perlu mengembangkan kecerdasan sosial mahasiswa dengan cara lebih mendorong mahasiswa untuk tetap aktif mengikuti SGD untuk merangsang mahasiswa belajar mandiri, belajar bekerja sama, mengemukakan pendapat, menghargai pendapat orang lain, dan menghargai pembagian tugas. Bagi mahasiswa perlu meningkatkan kecerdasan sosialnya dengan cara meningkatkan keterampilan berinteraksi dalam kelompok, sehingga memudahkan dalam bersosialisasi dan bekerja sama dalam kelompok SGD. Bagi peneliti selanjutnya diharapkan dapat melakukan penelitian serupa tidak hanya kepada mahasiswa pendidikan dokter, melainkan juga mahasiswa lain, siswa SMA, dan SMP untuk mengetahui hubungan kecerdasan sosial dengan kepuasan kerja sama kelompok dalam SGD, sehingga dapat diketahui apakah ada perbedaan kepuasan dalam kerja sama kelompok pada metode belajar SGD pada siswa SMA dan SMP. Diharapkan peneliti selanjutnya dapat melakukan penelitian serupa pada daerah di Bali selain Program Studi Pendidikan Dokter FK Unud agar mendapat karakteristik subjek yang berbeda dan bervariasi, sehingga data yang diperoleh lebih kaya dan beragam.

\section{DAFTAR PUSTAKA}

Azwar, S. (2005). Penyusunan skala psikologi. Yogyakarta: Pustaka Pelajar.

Amin, Z., \& Eng, K. H. (2003). Basic in medical education. United States America: World Scientific.

BBC. (2012, November 27). Peringkat sistem pendidikan Indonesia terendah dunia.http://www.bbc.com/indonesia/majalah/2012/11/121 127_education_ranks.shtml.Diunduh April 14, 2014

BBC. (2014, Juli 25). Indonesia butuh terobosan untuk tingkatkan akses pengetahuan. //www.bbc.com/indonesia/berita_indonesia/2014/07/14072 4_undp_pengembangan_manusia.shtml. Diunduh April 14, 2015 .

BPS. (2014). Bali dalam angka 2014. Denpasar: Badan Pusat Statistik Provinsi Bali.

Buzan, T. (2002). The power of social intelligence. New York: HarperCollins Publishers.

Cremer, H.W., \& Siregar, M. F. (1993). Permainan dan latihan dinamika kelompok proses pengembangan diri. Jakarta: Grasindo.

Devito, J. A. (1997). Komunikasi Antarmanusia (5th ed.). Jakarta: Professional Books.

Dewi, N. P. S. (2014). Pengaruh kecerdasan intelektual dan kecerdasan sosial terhadap prestasi belajar anak SD yang bersekolah sambil bekerja, bersekolah reguler, dan homeschooling. Studi Kasus (tidak dipublikasikan). Program Studi Psikologi Fakultas Kedokteran Universitas Udayana, Bali.

Gardner, H. (2003). Kecerdasan Majemuk. Batam: Interaksara. 


\section{HUBUNGN KECERDASAN SOSIAL DENGAN KEPUASAAN KERJA DALAM SGD}

Goleman, D. (2001). Kecerdasan Emosi untuk Mencapai Puncak Prestasi. Jakarta: Penerbit PT Gramedia Pustaka Utama.

Goleman, D. (2007). Social Intelligence: Ilmu Baru Tentang Hubungan Antar-Manusia. Jakarta: PT Gramedia Pustaka Utama.

Gusliza, N. (2013). Hubungan Komunikasi Interpersonal dengan Kepuasan Kerja Pegawai Dinas Pendidikan Pemuda dan Olahraga Kota Bukittinggi. Jurnal Administrasi Pendidikan , 1 (1), 163-172.

Hasibuan, J.J., \& Moedjiono. (1999). Proses Belajar Mengajar. Bandung: PT Remaja Rosdakarya.

HMKU FK UNUD. (2011, Maret Senin). Beragam sistem pembelajaran pada jurusan pendidikan dokter. http://hmkufkunud.blogspot.com/2011/03/beragam-sistempembelajaran-pada.html. Diunduh Feruari 12, 2015.

Ivancevich, J. M., Konopaske, R., \& Matteson, M. T. (2006). Prilaku dan manajemen organisasi. Jakarta: Erlangga.

Kartono, Kartini. (2006). Pemimpin dan kepemimpinan. Jakarta: PT RajaGrafindo Persada.

Kemendiknas. (2012, Meret 26). Sekolah menengah pertama. http://www.kemdiknas.go.id/kemdikbud/peserta-didiksekolah-menengah-pertama. Diunduh Maret 14, 2015.

Komnasham. (2015, Januari 22). UU No 20 Tahun 2003 tentang sistem pendidikan nasional. http://www.komnasham.go.id/instrumen-ham-nasional/uuno-20-tahun-2003-tentang-sistem-pendidikan-nasional. Diunduh April 12, 2015.

Krietner, R., \& Kinicki, A. (2014). Perilaku organisasi (9th ed.). Jakarta: Salemba Empat.

Makmun, A. S. (2007). Psikologi kependidikan perangkat sistem pengajaran modul. Bandung: PT Remaja Rosdakarya.

Muzayanah,A., \& Dian, IP. N. (2008). Hubungan antara kecerdasan interpersonal dengan kepuasan kerja karyawan (guru). Jurnal soul , 1(2), 32-46.

Myers, D.G. (2014). Psikologi sosial (10ed.). Jakarta: Salemba Humanika.

Semarayadnya, I. G. B. (2006, Oktober 6 ). Kerja sama menuntaskan problem pendidikan. http://www.balipost.co.id/balipostcetak/2006/10/6/o3.htm. Diunduh Maret 20, 2015.

Sholihah, I. M., Karyanto,P., \& Sugiharto, B. (2012). Kekuatan dan arah kemampuan metakognisi, kecerdasan verbal, dan kecerdasan interpersonal hubungannya dengan hasil belajar biologi siswa kelas XI IPA SMA negeri 3 Sukoharjo. Jurnal pendidikan biologi , 4 (1), 31-39.

Sindonews. (2013, Desember 13). Pendidikan universal untuk menggapai Indonesia Emas http://nasional.sindonews.com/read/815789/94/pendidikanuniversal-untuk-menggapai-indonesia-emas-1386750399

Slavin, R. E. (2008). Psikologi pendidikan teori dan praktek (8th Ed, Jilid Satu). Jakarta: PT Indeks.

Taylor, S. E., Peplau, L. A., \& Sears, D. O. (2009). Psikologi sosial (12th Ed). Jakarta: Predana Media Group. 